Psicossoma II. Psicossomática psicanalítica Rubens Marcelo Volich, Flávio Carvalho Ferraz, Maria Auxiliadora de A.C. Arantes (Orgs.) São Paulo, Casa do Psicólogo

1998

\title{
Navegações psicanalíticas pela psicossomática
}

\author{
Milton Lopes de Souza
}

O que é Psicossomática? Existirá um campo próprio, uma delimitação teórica, conceitos específicos? Será a psicossomática um terreno entre a medicina e a psicanálise, uma disciplina emergente em busca de um reconhecimento no meio científico, universitário ou psicanalítico? E quantos adjetivos poderemos propor para qualificála: psicossomática do adulto, psicossomática da criança, psicossomática psicanalítica, psicossomática cognitiva. psiconeuroimunologia...

Percorrendo a literatura, também notamos uma profusão de tentativas teóricas para dar conta de um grande ponto de interrogação para médicos e psicanalistas: corpo e psique, como unir dois aspectos que desde há no mínimo quatro séculos vêm sendo apresentados ao pensamento como separados. Mesmo Freud, ao estruturar a psicanálise, concebeu a psique como um aparelho e com respeito ao corpo, preferiu excluí-lo como objeto de estudo, pois queria que a psicanálise se constituísse como disciplina independente da medicina.

No entanto, deixou em aberto a questão da interferência ou a participação do inconsciente nos processos somáticos, que logo foi retomada por seus seguidores: Ferenczi, Groddeck, Alexander, Ballint... Esta inquietação a respeito das relações do inconsciente, da estruturação psíquica, do corpo imaginário e do corpo real continua até nossos dias, num campo de reflexão que podemos considerar como psicanalítico, ou seja, psicossomática psicanalítica. 
Psicossoma II - Psicossomática Psicanalítica apresenta como continuação de seu primeiro volume, o valoroso esforço de seus organizadores em reunir textos de diversos autores, a partir do amadurecimento de suas experiências clínicas, simpósios e reflexões realizadas no Instituto Sedes Sapientiae.

Tendo como eixo teórico principal as propostas da Escola de Psicossomática de Paris, fundada por Pierre Marty, Michel Fain e seus continuadores, os autores abrem espaços de diálogos interessantes com outros pensadores da psicossomática como Winnicott, Joyce McDougall, Christopher Bollas e J. Lacan.

A obra é didaticamente dividida em quatro sessões. Na primeira, "Novas perspectivas em Psicossomática", Sônia Maria Rio Neves e Wilson de Campos Vieira desenvolvem uma análise das diferenças entre as posições teóricas de P. Marty e M. Fain, principalmente no que diz respeito à pulsão de morte, modelo pulsional e neurose traumática.

Em um artigo especial, Christophe Dejours, psiquiatra e psicanalista francês e membro do Instituto de Psicossomática de Paris, expõe suas principais linhas de pensamento como as noções de subversão libidinal e atuação expressiva, a perspectiva sugerida pela dimensão relacional do adoecer, e os obstáculos que encontramos ao buscar compreender as relações entre psicanálise e biologia.

Na segunda sessão, "A Psicanálise e o Psicossoma", introduzida por Márcia de Mello Franco, Fernando Rocha convida-nos a refletir, a partir de um relato de caso, sobre a transformação do corpo bio-lógico em corpo psico-lógico, mostrando como sua paciente pôde mudar, através do processo analítico, sua maneira de lidar com situações de perda e separação, criando vias de simbolização que passaram a "proteger" seu corpo biológico.

Decio Gurfinkel, a seguir, apresenta as considerações do funcionamento psicossomático tal como concebe Winnicott em sua "teoria da mente". Para ele, o transtorno psicossomático poderia caracterizar a busca do restabelecimento da conexão psique-soma, perdida por consequiência de uma patologia dissociativa da mente.

Paulo Roberto Ceccarelli discute em seu trabalho sobre os "destinos do corpo", os momentos críticos do desenvolvimento para a constituição da identidade sexual, mostrando como a erogenização do corpo do bebê pela relação com os conteúdos inconscientes da mãe podem incorrer na total ou parcial discordância entre o sexo anatômico e a sexuação inconsciente.

Na sessão "Psicossomática da Criança", os autores abordam conceitos de Léon Kreisler, Winnicott, Spitz, Soulé e Debray sobre o infantil para refletir sobre a relação terapêutica e a noção de sucessão sindrômica na prática pediátrica, bem como sobre a importância dos distúrbios do sono na criança como paradigma terapêutico e teórico da psicossomática. Finalmente, Domingos Paulo Infante desenvolve, a partir do referencial lacaniano, alguns elementos para tentar 
compreender o gozo específico envolvendo o fenômeno psicossomático. Infante propõe retomar a perspectiva pulsional, bem como as dimensões real, simbólico e imaginário como referências para compreender a estruturação das funções corporais e a perturbação das mesmas.

Na sessão "Psicossomática, Saúde Mental e Trabalho", Flávio Carvalho Ferraz analisa a significação do trabalho para o homem, partindo de uma perspectiva histórica, econômica e ideológica, chegando através do conceito de alienação à leitura psicanalítica. Marcília de Araújo Medrado Faria e Leni Sato desenvolvem discussões acerca das patologias orgânicas e psicopatologias decorrentes do trabalho dentro do atual contexto sociocultural.

$\mathrm{Na}$ última parte desta coletânea, "Formação em Psicossomática", são questionadas as principais tendências atuais da prática e da formação médicas. Apesar do fascínio atual pelas perspectivas da biologia molecular e a esperança que ela suscita de previsão de doenças e comportamentos, Milton de Arruda Martins propõe que a medicina do século XXI deverá ser a medicina da multicausalidade e do diálogo interdisciplinar.

Rubens Marcelo Volich finaliza com uma reflexão sobre a formação em psicossomática a partir da consideração de que os caminhos que percorremos para concretizar nossas escolhas profissionais não se restringem apenas a seus aspectos técnicos ou curriculares, mas que esses processos são indissociáveis das dinâmicas estruturantes da identidade de cada um. Concentrando sua análise na concepção de um curso de psicossomática pós-universitário, ele o apresenta como lugar de convergência de discursos e práticas oriundos de diferentes campos de saber, aberto a todos aqueles que se deparam com a questão do desenvolvimento humano, da saúde e do adoecer. Descrevendo as principais linhas mestras e estudos que deveriam caracterizar esse curso, Volich acentua ainda a importância de que ele possa promover nesse processo um trabalho permanente de elaboração pessoal e de possibilidade de confrontação com as dúvidas que surgem ao longo do exercício profissional.

Trata-se, finalmente, de uma coletânea de textos que apresentam uma harmonia entre si, abordando várias questões pertinentes à psicossomática, que certamente servirá de referência para estudantes em formação e profissionais em busca de aprimoramento. 